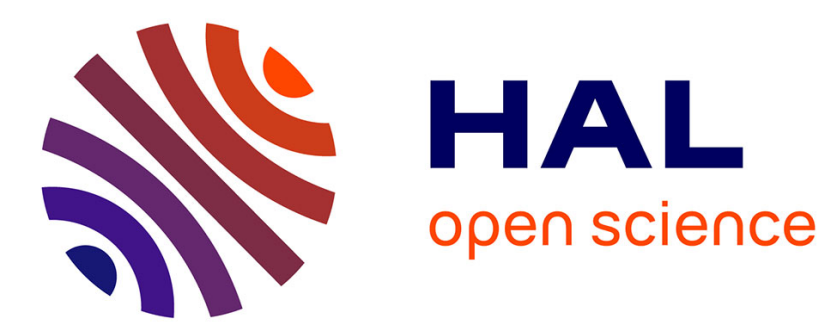

\title{
Energy futures from the social market economy to the Energiewende
}

\author{
Stefan Cihan Aykut
}

\section{To cite this version:}

Stefan Cihan Aykut. Energy futures from the social market economy to the Energiewende: The politicization of West German energy debates, 1950-1990. Jenny Andersson; Egle Rindzevičiūtè. Forging the Future, Routledge, pp.63-91, 2015. hal-01276134

\section{HAL Id: hal-01276134 \\ https://hal.science/hal-01276134}

Submitted on 18 Feb 2016

HAL is a multi-disciplinary open access archive for the deposit and dissemination of scientific research documents, whether they are published or not. The documents may come from teaching and research institutions in France or abroad, or from public or private research centers.
L'archive ouverte pluridisciplinaire HAL, est destinée au dépôt et à la diffusion de documents scientifiques de niveau recherche, publiés ou non, émanant des établissements d'enseignement et de recherche français ou étrangers, des laboratoires publics ou privés. 
Please cite as :

Stefan C. Aykut (2015), "Energy futures from the social market economy to the Energiewende: The politicization of West German energy debates, 1950-1990", in: Jenny Andersson, Egle Rindzevičiūtè, The Struggle for the Long Term in Transnational Science and Politics: Forging the Future, Routledge, Cultural History Series, 93-144 (to be published).

\section{$\underline{\text { Abstract: }}$}

The chapter tells the story of energy transformation (Energiewende) scenarios in West Germany. Based on abandonment of nuclear energy and its replacement by energy savings and renewable energy sources, as well as transformation of energy systems from centralized to decentralized production, transition scenarios profoundly influenced and transformed the German energy debate, while at the same time losing some of their more radical implications in the process of institutionalization in official expertise. By retracing this history, the chapter shows how energy forecasting in post-war Germany was embedded in political struggles over energy and economic policy, and how the use of scenarios by the environmental movement led to a politicization and pluralization of energy futures. 


\section{Chapter 3}

\section{Energy Futures from the Social Market Economy to the Energiewende}

\section{The Politicization of West German Energy Debates, 1950- 1990}

\section{Stefan Cihan Aykut}

This chapter analyzes the history of energy forecasts and scenarios in West Germany in the decades 1950-1990. It shows that forecasting techniques were crucial in structuring the emerging field of energy policy and analyzes them as sociotechnical objects that defined boundaries between scientific and political questions in German energy discourse. The first part of the chapter analyzes how forecasting techniques were introduced into energy debates at the global level and later in national policy-making. I also point to some scholarly debates about how to characterize the functions and effects of such techniques. The second part of the chapter deals with the role of energy forecasts from the late 1950s to the beginning of the 1970s. In this period, characterized by steady economic growth in what has been called the German "Wirtschaftswunder" ("economic miracle"), energy modeling techniques were concentrated in the hands a few economic research institutes, energy utilities and state administrations, and forecasts were mainly used as instruments directly intended for the policy process. ${ }^{1}$ They represented an attempt to create forms of foreseeability about evolutions in the energy field, and reflected a general trend to the "rationalization of politics." But forecasts were also part of a negotiation game that took place between government and energy utilities, as well as between 
different groups within government, over public investments in energy technologies, energy infrastructure and power plants. In fact, forecasting reenacted a post-war social contract based on steady economic growth and associated energy demand, and helped to forge a political compromise on energy policy comprising a simultaneous commitment to the dominant freemarket ideology and to the protection of the domestic coal sector. Forecasts also encapsulated optimistic visions about the future potential of nuclear energy, constituting the cornerstone of an emerging "economy of techno-scientific promise."2

The role of forecasting changed, however, by the end of the 1970s. The third part of the chapter discusses the emergence of energy turnaround (Energiewende) ${ }^{3}$ scenarios in West Germany. These scenarios appeared in the context of increasing controversies over energy policy after the two oil crises (1973 and 1979), but also in a situation of growing civil society resistance against nuclear energy. In other words, by the early 1980s, some of the cornerstones of post-war energy consensus in Germany crumbled. Elaborated by research institutes with close links to the anti-nuclear movement, energy turnaround scenarios constituted strategic devices in these controversies, and they used the scenario technique specifically in order to allow for the representation of contrasting alternative energy futures, thereby re-politicizing the energy debate. In particular, the chapter analyzes the first transition scenario elaborated by the newly founded Öko-Institut (Ecological Institute), in 1980, and shows how this scenario questioned, challenged and destabilized central elements of the post-war consensus.

The fourth part of the chapter looks at how the scenario technique was used in two German parliamentary commissions (Enquetekommission), in 1979-1980, and in 1987-1990. These commissions were organized at two very particular moments in time, in which fundamental understandings of energy policy were "unsettled"4 and energy futures hotly 
debated. The first commission was created after the Three Miles Island accident, the second one after the Chernobyl catastrophe and first public alerts in West Germany about an imminent "climate catastrophe." In the context of these two commissions, scenario methodology played a key role in the process of negotiating an energy future for West Germany. Scenarios were used to foster consensual recommendations about long-term goals and short-term actions, and allowed the commissions to present different conflicting future visions compatible with these goals. The commissions thus avoided taking an explicit stance in the controversy on nuclear energy, and helped alternative energy scenarios that had emerged out of the radical environmental debate of the 1970s to become accepted and included into official expertise. Scenarios of energy futures were also central, I propose, in a redrawing of boundaries between what should be considered as a "scientific" representation of the future, in other words one that could be delegated to expertsand what should be regarded as open for political discussion in the energy field. ${ }^{\mathbf{5}}$

In the concluding part, I point to how this analysis helps to understand in later developments, when the Energiewende became official government policy after 1998 (when a coalition government between Social Democrats and Greens decided to phase out nuclear and engage an energy transition) and 2011 (the re-affirmation of the energy transition by a liberalconservative government after the Fukushima accident).

\section{Forecasting Techniques and Energy Policy: From the Global to the National Level}

The role of forecasting techniques changed dramatically in the decades from the 1950s to the 1980s that are the focus of this chapter. "The future" became an object of study in the 1950s and 
1960s in a majority of industrialized countries. The first forecasting studies originated at the American RAND Corporation in a context of Cold War nuclear confrontation, ${ }^{6}$ whereas French planning circles developed and theorized "strategic forecasting" or "la prospective" as a method to rationalize decision-making and investment decisions for big industrial projects in a quickly changing sociotechnical environment. ${ }^{7}$ Whereas this first line of forecasting techniques were based on a belief in science and the "knowability" of the future, ${ }^{8}$ growing environmental consciousness, debates about possible Limits to Growth ${ }^{9}$ and the emancipatory impetus of the peace, civil rights and environmental movements inspired new approaches in the 1970s, including "doomsday scenarios" aiming to raise consciousness of the unsustainability of current lifestyles and production and consumption patterns, ${ }^{\mathbf{1 0}}$ the use of the scenario technique to represent alternative futures, ${ }^{11}$ and participatory future-making practices. ${ }^{12}$

Forecasting and scenario techniques were used extensively in the energy field throughout the analyzed period. The first global estimations of future energy demand are even older. They originated from the meetings of the World Power Conferences (the precursor of the World Energy Council), and were issued already in the 1920s. Several decades later, global studies like IIASA's Energy in a Finite World ${ }^{\mathbf{1 3}}$ modeled the global energy system and sketched possible future developments in energy consumption and production as a response to growing worries about limited energy resources. ${ }^{14}$ Since the 1990s, the International Energy Agency, an international organization founded in 1973 after the first oil crisis, has released annual forecasts called World Energy Outlook that constitute the global reference point for national debates about the evolution of energy systems.

At the national level, forecasting techniques were introduced in energy policy and used by energy utilities in the aftermath of Second World War, as national reconstruction and rapid 
economic growth, combined with a tendency toward increasing size in production units (electricity, heat) and the need to build new and ever more heavy and costly infrastructure (mines, refineries, pipelines, transmission lines, energy research, etc.), created a situation where return on investment was often only achieved in the medium or long-term. Public decisionmakers and energy companies therefore depended—and still depend—on projections of the evolution of energy demand, prices of different resources and technology developments for their investment decisions. But as this chapter will show, forecasting tools were used very differently from the 1950s to the 1980s, in the hands of different actors with different conceptions of energy futures that mobilized different forms of future-related expertise.

Forecasting techniques emerged in the 1950s and 1960s in Germany and elsewhere with the promise to "rationalize" energy policy-making through a clarification of available policy options and a structured discussion of their foreseeable effects. This was part of a wider trend to science-based policy advice in the legislative process. ${ }^{15}$ But a look at their history and the controversies and struggles of which they were objects suggests the "rationalization" paradigm describes rather poorly what forecasts actually do. ${ }^{16}$ Instead, the use of forecasts in the post-war period can be seen as part of a general trend to quantification in public policy that has been analyzed in great detail by scholars like Theodore Porter ${ }^{17}$ and Alain Desrosières ${ }^{18}$. Porter suggests that "quantitative technologies used to investigate social and economic life work best if the world they aim to describe can be remade in their image .... Quantification is simultaneously a means of planning and of prediction."19 Porter's argument echoes an older claim about selffulfilling prophecies in the social sciences ${ }^{20}$ and has been further developed in a literature on the performativity of economics. ${ }^{21}$ Following these insights, this chapter is interested in forecasts and scenarios not as mere representations but as agents of change. In the case of energy 
forecasts, the performativity claim is backed by the fact that official forecasting practices are clearly aimed to shape reality, rather than just describe possible or probable evolutions. Energy forecasts generally associate major public and industrial actors, and they include strong hypotheses on the future evolution of energy policies. Thomas Baumgartner and Atle Midttun show, in a comparative study on forecasting practices in Western Europe, that energy forecasts are closely associated with planning traditions. ${ }^{22}$ Their predictive power therefore stems less from sophisticated methods than from the way that they are used by actors and networks, in particular state administrations and energy companies that have a strong influence on the setting of prices, tariffs, on investments decisions, and so on. Other studies have argued that energy forecasting is essentially a means to legitimize political decisions made independently of modeling outcomes. ${ }^{23}$ Wynne, for example, shows in his in-depth study of IIASA's first global energy study Energy In A Finite World that energy system modeling emerged as a tool in order to grant an aura of objectivity to energy forecasts to the policy recommendations that could be drawn from them. ${ }^{24}$ From this point of view, politics is infused in forecasts through the institutional context of modeling exercises, ${ }^{25}$ and science is essentially a tool to back up policy decisions.

Forecasts had indeed performative effects and also a legitimizing function. But both of these paradigms finally stipulate the superiority of one set of actors and practices-either scientists and expertise, or politicians and ideology—over the other, and miss therefore the more subtle interplay between science and politics in the making of energy futures. I aim to show in the following analysis that forecasts and scenarios were part of a complex and contentious coproduction $^{26}$ process in which the shaping of scientific methods of foreseeability and the 
negotiation of a societal future for West Germany were closely intertwined and took place at the same time.

\section{Governing the Future: Energy Forecasts and the Soziale Marktwirtschaft}

The German state did not have a federal energy policy before 1973. In accordance with Germany's post-war ideology of market liberalism, market forces were to drive the development of energy infrastructure and the construction of new power plants. The absence of an explicit federal energy policy did not mean, however, that the state was not engaged in multiple ways and on different levels in the energy field: through subsidies and funding of energy-related research, through legislative or administrative rule-making affecting the building of transmission lines, power plants, and the extraction of resources, and as a market-actor through publicly owned companies on municipal (Stadtwerke) and state (Länder) levels. This entanglement between the regulator and regulated companies, together with a longstanding tradition of corporatism in what has been called the Deutschland $A G,{ }^{27}$ created a complex terrain for energy policy, whose main actors were the federal State, the Länder, municipalities, energy utilities, and big industrial consumers. $^{28}$

Four developments transformed, however, energy policy and representations of energy futures, as well as imaginaries and cosmologies in the post-war decades: spectacular economic growth and increased energy demand; quickly rising oil consumption; development of nuclear energy and what was known in German as Atomeuphorie or "atom euphoria"; and the opening of the German market to imported coal in 1956, when the creation of the European Community of 
Coal and Steel put an end to regulated prices. Together, these developments presented an unprecedented challenge to the domestic coal industry ${ }^{29}$ and provoked a spectacular rise in energy dependency from eight percent in 1960 to sixty percent in $1977 .^{30}$ The German coal industry entered a phase of decline, with production dropping from 103 million tons in 1950 to 80 million in 1973 and the overall share of coal in German energy production falling from ninety percent in 1950 to approximately thirty percent in 1970. As the coal industry employed some 433,000 workers in 1950, these evolutions were of high political significance. ${ }^{\mathbf{3 1}}$

As investments in new power plants exploded, with the development of ever bigger units in coal and gas, and later in the nuclear sector, ${ }^{32}$ forecasts were first used as planning tools by energy companies in their struggle to convince public and private funders of the necessity to keep investing in new projects (power plants, energy research, etc.). ${ }^{33}$ At the federal level, they were embedded in a different context, as the crisis in the German coal industry spurred heated debate in the government. In this debate, protectionists led by Chancellor Adenauer pledged for governmental support of the mining industry, whereas market liberalists around the minister of the economy Ludwig Erhard refused government help. Political tensions were exacerbated by the fact that Germany had for the first time become a net importer of energy resources in 1955 . In this context, Adenauer created a parliamentary commission on energy ("Energie-Enquête",34) in 1959, with the objective to calculate future energy demand and sketch expected evolutions of German coal. The commission produced a study on the basis of a ten-year forecast made by a consortium composed of major German economic institutes. ${ }^{35}$ The advanced methodology used in the study would become the standard in energy forecasting for the years to come. ${ }^{36}$ Two features of the forecast were particularly innovative: contrary to most earlier studies that had used an aggregated approach in which the national economy was analyzed as a whole, it 
disaggregated the economy in three major sectors-industry, transportation and householdsand went into further detail in the industry and transportation sectors (detailing three subsectors of each). This was combined with a detailed analysis of substitution processes between different forms of final energy ("modal mix": electricity, heat, movement) and of primary energy sources (“technology mix": coal, gas, oil, nuclear, hydro, etc.). This new approach reflected the political mandate of the commission, as the substitution method allowed more detailed estimations of future energy mixes, and especially of evolutions in the coal sector. The report also included, for the first time in the history of German energy forecasts, a discussion of uncertainties and of plausible alternative evolutions to the forecasted developments. The sectorial approach highlighted the ongoing substitution process between domestic coal and imported oil and gas, whereas the discussion of alternative evolutions gave them a political dimension. Through its method and its results, the report thus backed the call for government to take protective measures that would stop the decline of the German coal sector.

The report prepared a rare infringement to market ideology in German post-war politics. Several measures, intended to protect the coal industry, were introduced by the conservative government on the basis of the report, starting with the Electricity Production Act in $1965 .{ }^{37}$ In fact, the Energie-Enquête was the first of several studies that directly paved the way for new forms of public intervention in the energy sector: such forecasts of future demand would be produced as a basis for the elaboration of a federal energy policy after the first oil shock, and each of the several updates of the federal energy law after 1973 relied on an actualized forecast.

However, forecasts had been used before in West German energy debates. In the mid1950s, a debate erupted on the energy gap (Energielücke). This was fuelled by a report of the Research Centre of the Energy Industries at the Technical University in Karlsruhe. Published in 
1955, the report forecasted an energy crisis beginning in 1975 and peaking in 2000, with dramatic consequences for German industry. ${ }^{38}$ The assumption of energy shortages turned out to be wrong by the end of the 1950s, as cheap oil flooded energy markets. Nevertheless, forecasts in the 1960s still nourished fear of future shortages. Based on systematically overestimated projections of energy demand, ${ }^{39}$ forecasts would continue to call for massive public investments in the energy sector. At a first glance, the overestimations might appear to be a result of the technical assumptions that underpinned them: forecasts up until the end of the 1970s assumed a stable relationship between economic growth and energy demand, simply extrapolating future energy demand from past developments. They also assumed that energy prices were going to fall as a result of the ever-increasing availability of oil and the expansion of cheap nuclear energy. But both of these assumptions were highly political. Taken together, they reflected central features of the German post-war consensus: German soziale Marktwirtschaft (social market economy) was built on the promise of steady and stable growth. Such growth would give a growing middle class access to wealth and affluence and prevent social conflict. The federal government actively promoted economic growth. A central instrument was the Economic Stabilization Act (Stabilitätsgesetz), introduced in 1967 by the first coalition government of the Christian democrats (CDU/CSU) and the Social Democrats (SPD) by the minister of the economy Karl Schiller (SPD). It concretized the concept of Globalsteuerung "global steering" through the definition of four objectives for economic policy: stable prices, high employment, foreign trade equilibrium, stable economic growth. As trade-offs between them made their simultaneous pursuit almost impossible, these four goals were also called the "magical square" of economic policy. ${ }^{40}$ This had important implications for energy policy. In the eyes of decisionmakers, growth required access to cheap energy like oil and, in the future, nuclear power. But 
developing such cheap energy conflicted with two of the other policy objectives, as imported oil already unbalanced the foreign trade equilibrium and both oil and nuclear would increase the crisis in domestic coal production, causing massive unemployment. In this context, the political desire to support a nascent nuclear energy program, while also protecting the struggling domestic coal sector emerged as part of an economy of promise ${ }^{41}$ that permitted to apparently reconcile conflicting policy goals through a fundamentally optimistic vision of the West German economic and energy futures. This economy of promise - the German research literature coined the notion "surplus of hope" (Hoffnungsüberschuss) ${ }^{42}$ —was implicated in forecasting exercises through the systematic overestimation of future shares of nuclear and coal in the energy mix, combined with an underestimation of imported oil and gas. ${ }^{43}$

These post-war forecasts of the German energy market were generally produced by economic institutes with close ties to industry and government, and directly involved in the production of economic data and macroeconomic modelling. ${ }^{44}$ Energiewirtschaftliches Institut (EWI), founded in 1943 in Cologne, for example, that had a leading role in the Energieenquete, was (and is) financed by a consortium of the main energy companies and actors in the energy field, including Rheinisch-Westfälisches Elektrizitätswerk (RWE) and the highly coal-dependent land of North-Rhine Westphalia. Ifo Institut für Wirtschaftsforschung (Ifo, established in Munich, 1949) and Rheinisch-Westfälisches Institut für Wirtschaftsforschung (RWI, established in Essen, 1943), two other economic institutes with energy divisions, have close ties to industry. ${ }^{45}$ On the global level, this was later completed by the foundation of IIASA in Laxenburg, close to Vienna, an international institute that specialized in the production of global energy forecasts and was directed from 1975 to 1981 by Professor Wolf Häfele, a nuclear physicist and father and most prominent advocate of the German fast-breeder technology. 
These institutes developed econometric models that over time were increasingly sophisticated concerning energy production and consumption. ${ }^{46}$ By introducing complex modeling methodology that could only be understood and thus only be challenged by a handful of actors, these energy forecasts were a fundamental source of expertise for the West German state. Indeed, they served the federal government and its administration by legitimizing energy policy objectives of the social market economy. Dominant models were embedded in powerful actor networks and they reproduced those actors' views. ${ }^{47}$ This changed in the aftermath of the oil crises, as predictive models failed, but also with the emergence of new actors and methods as a result of the controversy over nuclear energy.

\section{Politicizing the Future: Energy Scenarios in the Nuclear Controversy}

The two oil crises (1973 and 1979) were a fundamental shock to this projected, stable future of increasing growth and energy consumption. The failure of dominant econometric models, based until now on the tight coupling of economic growth and energy demand, to predict and properly explain a situation where rising prices led to increased energy conservation, efficiency and a diminishing overall energy demand, triggered the development of new types of models and forecasting practices. ${ }^{48}$ A central economic controversy in this context was about the "elasticity" of energy demand, a notion that refers to the reaction of energy consumers to the variability of energy prices. Economic models were built on the premise that overall demand wasn't affected by prices, a dogma that was increasingly contested in the 1970 s. $^{49}$ This made it possible to think about ways to decouple growth from energy demand through more efficient use of resources. But 
forecasts also became objects of important forms of political contestation. This struggle led to a multiplication of contrasting forecasts and scenarios, which would no longer be elaborated only by state administrations, research institutes and energy companies, but also by experts close to the nascent environmental movement. ${ }^{50}$ In the wake of the oil crisis, energy forecasting thus evolved from an instrument of energy policy-making that underpinned the promises and ideological foundations of the German social market economy to a weapon in sociotechnical controversies, essentially over nuclear energy.

The development of alternative forecasts and their progressive establishment in the energy debate was the result of the growing strength of the German environmental movement. The construction site for a nuclear power plant at Wyhl, in the Rhine valley near Freiburg, was occupied by local farmers and activists in 1975 (it stayed occupied until 1977), and public opposition soon accompanied other planned constructions in the late 1970s, especially in Brokdorf (Schleswig Holstein), Grohnde (Lower Saxony) and Kalkar (North Rhine-Westphalia). A first peak of anti-nuclear protests was reached in 1977, when 40,000 people protested at Kalkar and 15,000 in Grohnde, in what would be depicted by the media as the "battle of Grohnde.” Inspired by the Wyhl protests, activists tried to occupy other construction sites, leading to fierce clashes with the police. The formerly peaceful demonstrations thus more and more culminated in violence. Despite this increasingly explosive situation and the radicalization of parts of the movement-fuelled through the fact that anti-nuclear protests in French Malville in 1977 had caused a first dead amongst the activists—-the German anti-nuclear movement continued to mobilize broadly around topics like the planned nuclear waste repository in Gorleben. In 1977, the federal government (Social Democrats) and the regional government (Christian Democrats) of North Rhine-Westphalia had decided to explore the possibility of 
storing nuclear waste at the former salt mine of Gorleben. The decision provoked local anger and national resistance and more than 100,000 opponents to atomic energy demonstrated in Hannover, the regional capital, on March 31, 1979. This was the largest demonstration the land—and the German anti-nuclear movement—had seen so far. A long series of legal cases against the construction of new nuclear power plants for safety reasons accompanied the direct militant actions in demonstrations and occupations, and gave experts close to the environmental movement a public forum. Soon, spontaneously created grassroots, popular education institutions like VHS Wyhler Wald (created in 1975), and independent research institutes like Öko-Institut (in 1977), went from providing information on the dangers of nuclear energy to informing about alternative energy sources, like solar collectors, photovoltaic panels or wind turbines.

Many ideas and new concepts used by the anti-nuclear movement came from the US, where President Carter (1977-1981) had initiated, as a response to the oil crisis and the taking of US hostages in Iran, a support program for renewable energy through favorable regulations and tax incentives that led to a (temporary) $)^{51}$ boom in renewable energy technologies. This was especially true for California, where incentives led to a rapid development of wind ${ }^{52}$ and solar ${ }^{53}$ energy. Along with these experiences came a new way of thinking the relationships between energy, environment, and the economy, embodied in new scientific approaches. Howard T. Odum, after having introduced system's thinking in ecology, now applied his "ecoenergetics" (the modeling of energy flows in a system) to American agriculture and shocked with the provocative thesis that "growing potatoes comes from fossil fuel." ${ }^{, 54}$ Alan Knees and Robert Ayres, ${ }^{55}$ among others, proposed to re-introduce material flows (from resources to production and waste) in economic analysis, laying the basis of what would later become the fields of ecological economics ${ }^{56}$ and industrial ecology. ${ }^{57}$ Amory Lovins, a physician working for Friends 
of the Earth International, published several path-breaking studies on energy in which he laid out a "soft path" in energy policy, that is, an energy strategy based on renewables and energy savings instead of centralized energy systems based on nuclear and fossil fuel power plants. He showed it to be technically feasible and economically viable ${ }^{58}$ and presented his results in official committees in several European countries, including as an invited expert in the German Enquete Commission on nuclear energy. These studies had in common the way that they re-introduced materiality, expressed in an idiom of cycles and flows derived from systems thinking and scientific ecology, in an energy discourse dominated by the disincarnated language of neoclassical economics. ${ }^{59}$ They were translated and transposed in the German debate through the work of a few pioneers like Klaus Michael Meyer-Abich, a physicist and philosopher who had done his dissertation with Carl Friedrich von Weizsäcker, a well-known German atomic physicists and one of the founders of peace studies. Meyer-Abich specialized in energy questions and was one of the first Germany researchers to adopt Lovins's proposal to consider energy savings as an actual source of energy. ${ }^{60} \mathrm{He}$ also proposed a research program on the "social compatibility" (Sozialverträglichkeit) of energy systems that built on Lovins's distinction between hard and soft energy paths. ${ }^{61}$

The foundation of the Öko-Institut in 1977 in Freiburg by actors who had participated in the protests in Wyhl marked a milestone, as it provided the environmental movement with a source of alternative energy expertise. Financed by a philanthropic association, the Institute soon established itself as an independent voice in German energy debates. Its "energy turnaround scenario, ${ }^{, 62}$ published in 1980, introduced a major innovation in forecasting techniques, as it proposed to use the scenario technique as a way of projecting possible alternative energy futures. Based on a bottom-up approach inspired by engineering expertise rather than economic theory, it 
allowed for more accurate representation of energy-saving potentials. It also modeled the possible contribution of decentralized renewables to energy production, and the impact of technological innovation in these fields. ${ }^{63}$ Politically, the energy turnaround scenarios were an answer of the environmental movement to the energy gap discourse that had informed post-war energy forecasts and had legitimized the massive investments into nuclear energy.

The three authors of the energy turnaround study were Florentin Krause, a chemist; Hartmut Bossel, an engineer and philosopher; and Karl-Friedrich Müller-Reissmann, a theologist and computer scientist. Together, they managed to assure support for their study from a variety of civil society actors, like the International Friends of the Earth Foundation (founded in 1969 in San Francisco, California, by former members of the Sierra Club), the Max-HimmelheberStiftung (a foundation of a German entrepreneur converted to the ecological cause, created in 1970 in Reutlingen, near Stuttgart) and the Forschungsstätte der Evangelischen Studiengemeinschaft (a protestant research institute founded in 1957/58 in Heidelberg). Krause, who had just obtained his $\mathrm{PhD}$ from the University of Berkeley, and Bossel, who had worked in Southern Californian as a mechanics teacher, had participated in numerous energy projects and also held a PhD from Berkeley, were also sufficiently aware of the American debate to translate some of its recent theoretical and practical developments into the German energy debate. ${ }^{64}$

The Energiewende report was designed rhetorically as an argument of guerilla warfare. Following a common slogan on guerilla warfare that suggests to "draw back your fist before you strike, ${ }^{, 65}$ the authors first made concessions to the dominant German energy discourse. In the subtitle, "growth and prosperity without oil and uranium," the authors indicated that their vision of a radical energy turnaround did not entail material sacrifices, and did not imply a radical departure from Germany's post-war ideology combining market liberalism and a social contract 
based on growth. Thus, the authors explicitly stressed—and regretted - that their scenario was not as radical as would have been an actual soft path scenario for Germany. They highlighted that they based their scenario on official growth prognosis, that it did not entail deep structural changes in the economy (e.g., deindustrialization or service economy, ${ }^{66}$ which would have been radical departures from industrialism), nor drastic changes in energy consumption patterns (for instance through life-style changes) or infrastructure (e.g. modal switch from road to rail). The authors thus qualified their method as a "technical fix scenario," aiming at satisfying projected energy needs even of "overtly growth-euphoric forecasts." 67 But they then operated a series of strategic displacements in the report, by redefining some basic notions and concepts from the established energy debate. Thus, they proposed a bottom-up approach based on "energy services" ${ }^{, 68}$ - heat, light, kinetic force, transportation, and so on—instead of aggregated demand, explicitly criticizing the domination of the energy discourse by economists and arguments derived from neoclassical theory. The main argument was that customers don't ask for particular energy carriers (coal, gas, oil) or kilowatt-hours of electricity, but for specific services. This made it possible to reconceptualize energy efficiency as a possible source of energy, and hence to popularize one of the main insights of Lovins' and Meyer-Abich's work in a way that was understandable for the general public. ${ }^{69}$ The report was also carefully designed to create alliances with major actors in the West German energy debate. Thus, despite the well-known ecological and health damages caused by coal, the report justified continued coal use, highlighting its quality as a domestic and German resource ("heimische Kohle"), thus building argumentative bridges to the trade unions and their historical ally, the SPD, as well as to the coal industry. After thus redefining the terms of the debate, the study concentrated its attacks on three particular elements of the German energy debate: first, the assumption of a tight coupling 
between economic growth and energy demand; second, the concentration of energy policy on the production-side; third, the reliance on oil and nuclear as basic pillars of the energy system. In other words, it focused on the very bulk of assumptions of post-war forecasts. The scenariotechnique played a central role in order to set this argument out.

Most of the report was consecrated to a detailed analysis of future energy needs and corresponding energy services. On the basis of this analysis, the report proposed three scenarios. ${ }^{70}$ The first one, a "business-as-usual" scenario ${ }^{71}$ assuming unchanged production and consumption patterns, was dismissed by the authors as economically, ecologically and politically unrealistic. ${ }^{72}$ The second one, labeled "Coal and Gas," was a concession to those who "don't give much on renewables. ${ }^{, 73}$ These two scenarios were set up, in fact, to privilege the third one, "Sun and Coal," which clearly had the favor of the authors and was qualified as "most realistic." The authors argued that increasing reliance on oil was not an option, as debates about "peak oil" suggested the resource was scarce and prices prone to increase sharply in the future. They also dismissed its substitution with nuclear energy because of the hidden costs and risks associated with this form of energy (risk of major accidents, unresolved nuclear waste storage, etc.). Both oil and nuclear energy, as well as gas, were also criticized for being imported resources, hence undermining German energy autonomy, whereas the "sun and coal" scenario had the unique advantage of granting near self-sufficiency to German energy needs.

The report did not call for de-growth or zero growth. This was advocated in the American debate by figures like Kenneth E. Boulding, a heterodox economist, system scientists and dedicated Quaker who theorized in "The Economics of the Coming Spaceship Earth",74 an economy with minimal resource use and waste production, or Herman E. Daly, one of the founders of ecological economics, who advocated a "steady-state economy, 
"uneconomic growth" and the modernist belief that technological progress would always make up for the scarcity of natural resources. Such radical voices, however, weren't audible in the mainstream of the German public debate where growth was considered a necessity after the deprivations of the war and the years of reconstruction. Thus, by concentrating on the decoupling of growth from energy demand instead of zero growth, the energy futures expressed in the Energiewende report stayed compatible with dominant themes in German post-war debate and were rendered acceptable for a larger part of the German population.

The first reactions to the report were nonetheless hostile: the study received little media attention, ${ }^{76}$ and a group from Kernforschungszentrum (KFA) Jülich, a major nuclear power research institution, issued a counterpamphlet with the similar title "Energiewende?" to refute the arguments of the Öko-Institut. ${ }^{77}$ But this attack backfired: entering grounds that were unfamiliar to them, the nuclear researchers themselves made miscalculations that they had to correct before finally withdrawing their counter-report altogether. ${ }^{78}$ If anything, the KFA Jülich report finally resulted in increased publicity to the theses of the Energiewende report.

The long-term influence of the Energiewende scenario on German energy discourse can hardly be overestimated. It certainly succeeded in its claim to re-politicize the energy debate by redefining what is an objective practical constraint (,Sachzwang“) and what should be seen as a

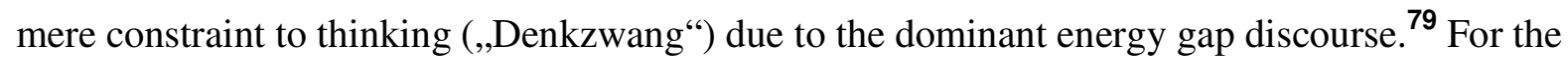
authors of the study, official forecasts that consistently overestimated future energy demand were technocratic instruments unduly narrowing down the range of possible energy futures, whereas such expertise should instead be opening up spaces for political decision-making and public debate. The success of the report was not only due to the originality of the study, but at least as much to the political context of the late 1970s and early 1980s. After the Three Mile Island 
accident in 1979, 100,000 people demonstrated in Bonn against nuclear energy. In 1983, the Greens entered the German Bundestag, putting a rapid end to nuclear power on the agenda, and using the reports of the Öko-Institut to back this claim. The nuclear accident of Chernobyl in 1986 finally popularized the theses of the report widely, and Öko-Institut's call to create local Energiewende committees in German towns and municipalities was followed by hundreds of local citizen's initiatives. These brought the main topics of the report-focusing on energy savings and renewables - to the attention of rural communities and local decision-makers.

Perhaps the most important effect of the Energiewende scenario was to re-open the future horizon of the German energy debate. By contesting official energy futures and proposing an alternative vision, the political dimensions and effects of these futures could also be contested on new grounds. The Energiewende report gave anti-nuclear militants a "grasp on the future," ${ }^{, 80}$ and the future scenarios that it comprised were an important resource in their struggle against the nuclear establishment. But it also illustrated and reinforced a growing schism within environmentalism, between more radical interpretations of the limits discourse by de-growth activists mostly in the US and in France, and moderate accounts in Germany that claimed that a deep transformation of the energy system could be accomplished within a reformed Social market economy. Among the proponents of this second vision, Hans Christoph Binswanger, a Suisse economist from the University of Sankt Gallen, was very influential. Binswanger published, together with two German economists-Holger Bonus and Manfred Timmermann from the University of Cologne—a book called Economy and Environment, in which he called for a more efficient use of resources through an ecological tax reform. ${ }^{81}$ In this book and in follow-up publications, he coined the idea of a "double dividend", claiming that an ecological tax reform would benefit both the employment and the environment. Two other representatives of 
this line of thought, Joseph Huber ${ }^{82}$ and Martin Jänicke, ${ }^{83}$ went even further and proposed to reconcile growth-based economic policy and environmentalism through what they called "ecological modernization." 84 The transformations in the energy sector laid out in the Energiewende report were a central argument in their reconceptualization of environmental policies as industrial policies.

\section{Negotiating the Future: Scenarios in Parliamentary Enquete Commissions}

The alternative visions expressed in the Energiewende scenario would be progressively institutionalized in the German energy debate, as the Öko-Institut was asked to contribute scenarios to two parliamentary Enquete Commissions- the first one on "future nuclear energy policy" (Zukünftige Kernenergiepolitik, 1979-1982), and the second on "precaution for the protection of the Earth's atmosphere" (Vorsorge zum Schutz der Erdatmosphäre, 1987-1990). The scenarios elaborated by the institute on these occasions were halfway between the two energy paths, "Coal and Gas" and "Coal and Sun," of the original Energiewende report. Through these two commissions, the radical Energiewende scenarios were transformed into an official option for the West German energy future.

These two commissions are of particular interest because they profoundly influenced the German energy debate and because of the particular use the commissions made of the scenario instrument. Organized in the aftermath of major nuclear accidents, the commissions formulated different "energy paths" that described energy futures with and without nuclear energy. The first commission's influence was mainly discursive, in the sense that its use of the scenario 
technology and its working procedures set a methodological standard for parliamentary energy expertise and because its results were taken up in subsequent commissions. The second commission influenced policy-making more directly, as it was instrumental in the preparation of an ambitious German climate change strategy. Furthermore, recommendations of the second commission were issued unanimously, whereas the Christian democrats withdrew their support from the conclusions of the first commission just before the publication of the results. Both, however, participated in a progressive "democratization of energy policy" and enabled the Bundestag to emancipate itself from government energy policy.

Following a parliamentary reform in 1969, Enquete Commissions became a particular feature of German parliamentary life. Since then, their mandate is larger than classical parliamentary enquiry. ${ }^{85}$ Used by parliament (Bundestag or regional parliaments) to prepare decisions on "complex and important subjects," ${ }^{86}$ Enquete Commissions came about as part of an attempt to make parliament more independent from ministerial expertise and increase public accountability in a context of growing critique of technocracy and demands to increase transparence and accountability in public policy-making. ${ }^{87}$ These commissions are composed in a particular way: half of their members are members of parliament, the other half are experts, named by the political parties represented in parliament. Thus, experts are not only called in for hearings, they are full members of the commission (including the right to vote) and work together with the parliamentarians throughout the commission's duration. A corollary of this practice is that in politically sensitive topics, the choice of experts is a highly disputed process, and experts are generally chosen not only because they are specialists of a particular topic, but also because they represent a particular social force, political position, or viewpoint. Sheila Jasanoff has described this particular German way of organizing policy knowledge, or public 
expertise, as a "civic epistemology," ${ }^{, 88}$ marked by the principles of inclusion, representation and rational dialogue between relevant viewpoints. ${ }^{89}$ The flip side of this way of organizing expertise is the risk of corporatist cooption. ${ }^{90}$ In the two commissions mentioned earlier, invited experts were mainly chosen depending on their stance on nuclear energy—experts close to the industry or nuclear research institutes were counterbalanced with others having close ties to the environmental movement and to alternative energy research. Significantly, both commissions included a member from the newly founded Öko-Institut.

The 1979 commission $^{91}$ was created at a crucial moment: the Wyhl construction site had been occupied by the antinuclear movement for almost two years; there had been violent clashes in Brokdorf, and heated controversy over the planned Kalkar Superphoenix — a fast-breeder reactor constructed since 1973 that was to make Germany less dependent on importations of nuclear material and solve its nuclear waste problem, but that was criticized by opponents as far too expensive and even riskier than regular nuclear plants. In neighboring Austria, a popular vote had been organized on the "Zwentendorf" nuclear power plant. Although the plant had already been built, the Austrian population rejected nuclear power in an extremely close vote (fifty-one percent to forty-nine percent). In German politics, growing division and publicly voiced discontent on nuclear energy within the two parties of the governmental coalition, the Social Democrats and the liberals of the Freie Demokratische Partei, was further exacerbated by the highly publicized nuclear accident at Harrisburg in 1979. In this heated atmosphere, the stated aim of the commission was to canalize the "emotional" nuclear controversy into "rational" and "reasoned" debate. ${ }^{92}$ The fifteen commission members believed this could be attained through the systematic clarification of different options and the implications of these options in political, 
social and economic terms. This led them to propose four energy paths, two with and two without nuclear energy.

The first of these scenarios corresponded roughly to the earlier social market economy consensus and reflected the vision of the energy utilities. It projected a doubling of energy demand until 2030, most of which was to be satisfied through nuclear energy. The second scenario expressed a more moderate view, commonplace amongst energy experts close to the nuclear industry. It projected a fifty percent increase in energy demand and a more moderate increase in nuclear energy. In the third scenario, demand was stabilized and nuclear energy was progressively phased-out. The fourth scenario built on the Öko-Institut report and projected a rapid nuclear phase-out, combined with heavy energy savings. A central feature of the commission's methodology was the establishment of a list of "common criteria" to evaluate the different scenarios. These criteria included economic viability, environmental impact, international compatibility, and social acceptability. This emphasis on the possibility of systematic evaluation of the scenarios was what enabled the commission to make authoritative policy recommendations.

The compromise proposed by the 1979 Enquete Commission was intended to give both the "hard path" (based on nuclear and fossil fuels) and the "soft path" (based on energy savings and renewables) a fair chance. It advocated to follow a "parallel approach" in energy policy for a 10 year period beginning in 1980: pursuing the construction of the Kalkar fast-breeder reactor on the one hand, but implementing an extremely stringent energy saving policy on the other. The members of the commission justified this parallel approach by the fact that key factors like the rapidity of structural changes in the economy and the evolution of public acceptance of nuclear energy, as well as the impact of energy saving measures and the final economic and technical 
feasibility of the fast-breeder technology, could simply not been foreseen properly. The final decision on which path to choose was therefore postponed to 1990 , when the consequences of these developments would be clearer.

By elaborating several different energy paths, establishing a set of evaluation criteria, and forging consensual recommendations for the next ten years, the commission delegated the final decision on the structure of the German energy system to the political system. The fact, however, that it considered a nuclear phase-out to be a viable option at all, was an important success for the anti-nuclear movement.

Following the Chernobyl accident in 1986, the German energy debate was again repoliticized. Chernobyl gave a new dynamic to the anti-nuclear movement and accelerated the German social democrat's turnaround on nuclear energy. ${ }^{93}$ But the year 1986 also marked the beginning of a broad public debate on climate change. The initial impetus for this debate came from a short pamphlet issued by the energy working group of the German physician's association, which warned of an "impending man-made climate catastrophe," a message that was taken up by the news magazine der Spiegel in a title story shortly after. ${ }^{94}$ This was the starting point of the German climate debate, with its characteristic alarmist tone. ${ }^{95}$ Chancellor Kohl publicly expressed his worries about climate change and his Christian Democratic party proposed to create a parliamentary commission on ozone and climate change, thus covering the two closely related new global environmental threats and sharpening the ecological profile of the party. Other political powers-especially the strongly anti-nuclear Greens and the Social Democrats - were more skeptical of the climate topic at the beginning, as they feared it might overshadow the debate on the risks of nuclear energy, and as they suspected, not without reason, that this was the main reason for Kohl's conservative party to push for it. 
A second parliamentary commission was nevertheless created in 1987. It was composed of eighteen members, with nine scientists coming from different branches of the atmospheric sciences (four members), energy and economical sciences (four members) and international law (one member). It issued a report that comprised a scientific analysis of the ozone hole and climate change problems, a discussion of the international energy situation, and the respective responsibilities of different countries, as well as a blueprint for an international climate convention. The heart of the report, however, was constituted by 420 pages on energy policy, including a reference scenario and three scenarios that responded to a fixed objective of thirty percent reductions of $\mathrm{CO}_{2}$ emissions. The difference between these three scenarios was to be found mainly in the projections concerning the use of nuclear energy. The first scenario, "Energy policy," was based on the assumption of a stable development of nuclear energy, while market forces were to drive the composition of the rest of the energy mix. The second energy path, "Nuclear expansion," aimed at meeting the reduction essentially through an industrial energy policy whose objective was to substitute nuclear to coal. The third scenario finally, "Nuclear phase-out," proposed a progressive substitution of nuclear by renewables, gas and energy savings until $2005 .{ }^{96}$ Like the 1979 commission on nuclear energy, the climate commission used the scenario methodology to issue consensual recommendations while explicitly delegating the question of nuclear energy to the political system. This was expressed in the commission report as follows:

The commission is convinced that the dangers that result of the enhanced greenhouse effect can only be avoided if the political system endorses the leading role that democracy assigns to it . . f for the commission, this results in the task to adopt a discursive working method for decision-making, in which political 
agreement as well as factual discord are laid out, and currently consensual and divergent standpoints are made transparent. ${ }^{97}$

This "discursive working method" comprised the inclusion of divergent opinions of commission members in the core of the report, as well as an active communication strategy towards the general public and the participation of the commission members to public hearings. This led to a wide discussion of the three energy scenarios and their implications.

The two Enquete Commissions led to a second discursive decoupling: just as the original Energiewende study had contributed to separating the debate about nuclear phase-out from radical growth critique, the Enquete Commissions' use of the scenario technique resulted in a progressive separation of the nuclear and climate change debates in German energy discourse. In other words, the Enquete Commission reports made it difficult for proponents of nuclear energy to argue that nuclear energy was necessary to combat climate change, because the energy paths of the second Enquete Commission officially showed that it was possible to pursue an ambitious $\mathrm{CO}_{2}$ reduction target and shut down German atomic energy. The situation therefore was very different for example from neighbor France, where climate change became a major argument in the debate on a hypothetic "nuclear re-launch.",98 Again, this displacement of the debate was the result of a partial re-negotiation of the science-policy border in the energy debate, as the experts of both commissions had refused to recommend particular energy technologies in response to the climate change threat.

\section{Three Moments of "Decoupling" and the Institutionalization of the Energiewende}


The analysis in this chapter shows that the "future" in energy forecasts is not something outside the present. It is on the contrary closely tied to the political, social and scientific debates of the time when the forecasts were made. ${ }^{99}$ In other words, the future of scenarios tells us more about the society that made those scenarios than about the future itself. In West Germany, energy forecasts reflected fundamental values and normative assumptions about economic growth, social stability and the desirability of specific energy technologies that were embedded in forecasting practices, economic theory and modeling techniques. As a consequence, the evolution of West German society and politics was reflected in and shaped by the forecasts and scenarios we discussed here.

This has implications for the study of foresight practices and social movements: what some regretted as a progressive "scientization" of the ecological movement through increasing reliance on expert knowledge has indeed led to an opening up of energy futures the West German energy debate. The future became political ${ }^{\mathbf{1 0 0}}$ in the sense that social movements used the instrument of scenarios to engage in energy controversies. Alongside the occupation of construction sites, mass demonstrations and the blocking of nuclear transports, scenarios emerged as a part of the contentious repertoire ${ }^{101}$ used by the anti-nuclear movement to make its voice heard and influence German energy policy.

Another important conclusion is that the effects of forecasts and scenarios depend on the uses that actors make of them, the practices attached to them and the political struggles they are embedded in. Just as Harro van Lente and Arie Rip conceptualize expectations in technological development as "prospective structures to be filled with in by agency,"102 Energiewende scenarios influenced West German energy policy because they were appropriated by local actors and through their progressive institutionalization in official parliamentary expertise. 
I suggest that this institutionalization has been facilitated by three moments of "discursive decoupling" between different discourses, operated through the different scenarios and forecasts in each of the analyzed periods: first, economists and energy specialists discussed in the 1970s the thesis that economic growth and energy demand could be decoupled, meaning that in energy efficient countries, strong economic development could be attained without comparable increases in overall energy demand. Second, the authors of the Energiewende report built on this argument and increased public acceptance of their energy vision by separating their argument for the necessary transformation of the German energy system from more radical critiques of economic growth. Finally, the members of the 1987 parliamentary Enquete Commission used the scenario technique to separate the debate on the future of nuclear energy from the debate on climate change.

Today, the historical window in which a pluralization of energy futures took place may be closing again, as the official energy vision expressed in the Energiekonzept "energy concept" for the Bundesrepublik, a plan defining goals and a schedule until 2050 for the evolution of the German energy system concerning the nuclear phase-out, the increase of renewables and of energy efficiency, as well as emission reduction targets, emerges as a unique official future designed to put the actors of the German energy turnaround to work. Similar to the late 1970s, however, contestation by social movements of the direction taken by the Energiewende may well result in the emergence of new alternative future visions that re-politicize parts of the energy debate. 


\section{References}

Altenburg, Cornelia Kernenergie und Politikberatung. Die Vermessung einer Kontroverse.

Wiesbaden: VS Verlag für Sozialwissenschaften, 2010.

Altenburg, Cornelia "Wandel und Persistenz in der Energiepolitik: Die 1970er Jahre und die Enquete-Kommission 'Zukünftige Kernenergie-Politik'.” In Energie in der modernen Gesellschaft. Zeithistorische Perspektiven, edited by Hendrik Ehrhardt and Thomas Kroll, 245-264. Göttingen: Vandenhoeck \& Ruprecht, 2012.

Andersson, Jenny “The Great Future Debate and the Struggle for the World.” American Historical Review 117, no. 5 (2012): 1411-1431.

Andersson, Jenny, and Egle Rindzevičiūtè. "The Political Life of Prediction: The Future as a Space of Scientific World Governance in the Cold War Era." Les Cahiers européens de Sciences Po 4 (2012): 1-25.

Baumgartner, Thomas and Adle Midttun. The Politics of Energy Forecasting: A Comparative Study of Energy Forecasting in Western Europe and North America. Oxford: Clarendon Press, 1987.

Beck, Silke "Localizing Global Change in Germany." In Earthly Politics. Local and Global in Environmental Governance, edited by Sheila Jasanoff and Marybeth Long-Martello, 173-194. Cambridge, MA and London: MIT Press, 2004.

Beyer, Jürgen “Deutschland AG a.D.: Deutsche Bank, Allianz und das Verflechtungszentrum großer deutscher Unternehmen.” MPIfG Working Paper 02/4 (2002). 
Binswanger, Hans Christian, Holger Bonus, and Manfred Timmermann. Wirtschaft und Umwelt. Möglichkeiten einer ökologieverträglichen Wirtschaftspolitik. Stuttgart: Kohlhammer, 1981.

Boulding, Kenneth E. “The Economics of the Coming Spaceship Earth.” In Environmental Quality in a Growing Economy, edited by Henry E. Jarrett, 3-14. Baltimore: Resources for the Future/Johns Hopkins University Press, 1966.

Brown, Nick, Brian Rappert, and Andrew Webster, eds. Contested Futures: A Sociology of Prospective Techno-Science. Aldershot, UK: Ashgate, 2000.

Chateauraynaud, Francis “Des prises sur le futur. Regard analytique sur l'activité visionnaire.” In Du risque à la menace. Penser la catastrophe, edited by Dominique Bourg, Pierre-Benoît Joly, and Alain Kaufmann, 287-309. Paris: PUF, 2013.

Chateauraynaud, Francis "Sociologie argumentative et dynamique des controverses: l'exemple de l'argument climatique dans la relance de l'énergie nucléaire en Europe." A contrario 16, no. $2011 / 2$ (2011): 131-150.

Common, Michael, and Sigrid Stagl. Ecological Economics: An Introduction. Cambridge, UK: Cambridge University Press, 2005.

Daly, Herman E. Toward a Steady-State Economy. San Francisco, CA: Freeman, 1973.

Der Spiegel. „,Tüftler im Grünen.“ Der Spiegel 36 (1980): 225-229.

Der Spiegel. "Jülicher Eigentor." Der Spiegel 48 (1980): 140.

Der Spiegel. “Ozon-Loch, Pol-Schmelze, Treibhaus-Effekt, Forscher warnen: Die KlimaKatastrophe.” Der Spiegel 33 (1986): 1.

Desrosières, Alain Pour une sociologie historique de la quantification. L'argument sociologique I. Paris: Presses de l'Ecole des Mines, 2008. 
Dieckhoff, Christian Modellierte Zukunft. Zur Theorie und Praxis von Energieszenarien im Kontext wissenschaftlicher Politikberatung. PhD diss., Karlsruher Institut für Technologie, 2014.

Diefenbacher, Hans, and Jeffrey P. Johnson. "Energy Forecasting in West Germany:

Confrontation and Convergence." In The Politics of Energy Forecasting: A Comparative Study of Energy Forecasting in Western Europe and North America, edited by Thomas Baumgartner and Adle Midttun, 61-84. Oxford: Clarendon Press, 1987.

Ehrlich, Paul R. The Population Bomb. New York: Sierra Club/Ballantine Books, 1968.

Flechtheim, Ossip K. Futurologie_Der Kampf um die Zukunft. Köln: Wissenschaft und Politik, 1970.

Fraunholz, Uwe, Thomas Hänseroth, and Anke Woschech. "Hochmoderne Visionen und Utopien. Zur Transzendenz technisierter Fortschrittserwartungen.” In Technology Fiction. Technische Visionen und Utopien in der Hochmoderne, edited by Uwe Fraunholz and Anke Woschech, 11-24. Bielefeld: transcript, 2012.

Frosch, Robert A. and Nicholas E. Gallopoulos. "Strategies for Manufacturing.” Scientific American 261, no. 3 (1989): 144-152.

Grunwald, Armin “Der Lebensweg von Energieszenarien-Umrisse eines Forschungsprogramms.” In Energieszenarien. Konstruktion, Bewertung und Wirkung”Anbieter" und "Nachfrager” im Dialog, edited by Christian Dieckhoff, Wolf Fichtner, Armin Grunwald, Sarah Meyer, Michael Nast, Linda Nierling, Ortwin Renn, Alfred Voß, Martin Wietschel, 11-24. Karlsruhe: KIT Scientific Publishing, 2011.

Haaf, Günter “In den Kloaken der Zivilisation.” Die Zeit 42 (10 October 1980): 101. 
Habermas, Jürgen "Verwissenschaftlichte Politik in demokratischer Gesellschaft." In Forschungsplanung. Eine Studie über Ziele und Strukturen amerikanischer Forschungsinstitute, edited by Helmut Krauch, Werner Kunz, and Horst Rittel, 130-144. Wien, München, 1966.

Hagen, Joel B. An Entangled Bank: The Origins of Ecosystem Ecology. New Brunswick, NJ: Rutgers University Press, 1992.

Hardin, Garrett “The Tragedy of the Commons.” Science 162 (1968): 1243-1248.

Hecht, Gabriele The Radiance of France: Nuclear Power and National Identity after World War II. Cambridge, MA: MIT Press, 1998.

Hockenos, Paul "The Energiewende.” Zeit Online (November 15, 2012). URL: http://www.zeit.de/2012/47/Energiewende-Deutsche-Begriffe-Englisch [retrieved 27.01.2015]

Hourcade, Jean-Charles "Les modèles dans les débats de politiques climatiques : entre le capitole et la roche tarpéienne ?" In Les modèles du futur, edited by Amy Dahan, 140-164. Paris: La Découverte, 2007.

Hulme, Mike “After Climategate . . Never the Same.” In Exploring Climate Change through Science and in Society: An Anthology of Mike Hulme's Essays, Interviews and Speeches, 252-264. Abingdon, UK: Routledge, 2013.

International Institute for Applied Systems Analysis [IIASA]. Energy in a Finite World: Paths to a Sustainable Future. Cambridge, MA: Ballinger Publishing Company, 1981.

Jasanoff, Sheila Designs on Nature. Science and Democracy in Europe and the United States. Princeton: Princeton University Press, 2005. 
Jasanoff, Sheila “The Idiom of Co-Production.” In States of Knowledge: The Co-Production of Science and Social Order, edited by Sheila Jasanoff, 1-12. London and New York: Routledge, 2004.

Joly, Pierre-Benoît "On the Economics of Techno-Scientific Promises." In Débordements. Mélanges offerts à Michel Callon, edited by Madeleine Akrich, Yannick Barthe, Fabian Muniesa, and PhilippeMustar, 203-222. Paris: Presse des Mines, 2010.

Kaldellis, John K. and Dimitris Zafirakis. "The Wind Energy (R) Evolution: A Short Review of a Long History.” Renewable Energy 36, no. 7 (2011): 1887-1901.

Keepin, Bill “A Technical Appraisal of the IIASA Energy Scenarios.” Policy Sciences 17, no. 3 (1984): 199-276.

Kleinwächter, Kai “Das 'Eiserne Pentagramm“-Strommarktregulierung in Deutschland.” In Deutsche Energiepolitik, edited by Lutz Kleinwächter, 65-79. Potsdam: Brandenburgische Landeszentrale für politische Bildung, 2007.

Kneese, Alan, Robert U. Ayres, and Ralph C. D’Arge. Economics and the Environment: A Materials Balance Approach. Baltimore: John Hopkins Press, 1970.

Knelangen, Wilhelm “Enquete-Kommissionen.” In Handwörterbuch des politischen Systems der Bundesrepublik Deutschland. (4te Auflage), edited by Uwe Andersen and Wichard Woyke, 157-159. Opladen: Leske+Budrich, 2000.

Kraus, Michael Energieprognosen in der Retrospektive. Analyse von Fehlerursachen der Prognose/Ist-Abweichungen von Energiebedarfsschä̈zungen in der Bundesrepublik Deutschland von 1950 bis 1980. PhD diss., Universität Karlsruhe, 1988. 
Krause, Florentin, Hartmut Bossel, and Karl-Friedrich Müller-Reissmann. Energie-Wende: Wachstum und Wohlstand ohne Erdöl und Uran. Ein Alternativ-Bericht des Öko-Instituts. Frankfurt am Main: Fischer, 1980.

Krisp, Annika Der deutsche Strommarkt in Europa-zwischen Wettbewerb und Klimaschutz. PhD diss., Fachbereich Sozial- und Kulturwissenschaften der Justus-Liebig-Universität Gießen, 2007.

Lascoumes, Pierre and Patrick Le Galès. "From the Nature of Instruments to the Sociology of Public Policy Instrumentation.” Governance 20, no. 1 (2007): 1-21.

Lehbert, Berndt “Untersuchung der kurz- und langfristigen Elastizitäten der Energienachfrage in bezug auf die Energiepreise in der Bundesrepublik Deutschland.” Kieler Arbeitspapiere Vol. 59. Kiel: Institut f. Weltwirtschaft, 1977.

Lovins, Amory B. "Energy Strategy: The Road Not Taken.” Foreign Affairs 55 (Fall 1976): 6596.

Lovins, Amory B. Soft Energy Paths: Toward a Durable Peace. New York: Penguin Books, 1977.

Lovins, Amory B. "The Negawatt revolution." Across the Board XXVII, no. 9 (1990): 18-23. Mackenzie, Donald "Making Things the Same: Gases, Emission Rights and the Politics of Carbon Markets.” Accounting, Organizations and Society 34, no. 3-4 (2009): 440-455.

Meadows, Donatella H., Denis L. Meadows, Jorgen Randers, and William W. Behrens III. The Limits to Growth: A Report to the Club of Rome. New York: Universe Books, 1972. Merton, Robert K. "The Self-Fulfilling Prophecy." Antioch Review 8, no. 2 (1948): 198-210. 
Meyer-Abich, Klaus Michael Energieeinsparung als neue Energiequelle. Wirtschaftspolitische Möglichkeiten und alternative Technologien. Mit einem Vorwort von Carl Friedrich von Weizsäcker. München: C. Hanser, 1979.

Meyer-Abich, Klaus Michael and Robert A. Dickler. "Energy Issues and Policies in the Federal Republic of Germany.” Annual Review of Energy 7 (1982): 221-259.

Meyer-Abich, Klaus Michael, and Bertram Schefold, eds. Wie möchten wir in Zukunft leben?

Die Sozialverträglichkeit von Energiesystemen. Band 1. München: C.H.Beck, 1981.

Mol, Arthur P.J., and Martin Jänicke. “The Origins and Theoretical Foundations of Ecological Modernisation Theory.” In The Ecological Modernisation Reader: Environmental Reform in Theory and Practice, edited by Arthur P.J. Mol, David A. Sonnenfeld, and Gert Spaargaren, 17-27. London and New York: Routledge, 2009.

Müller-Reissmann, Karl-Friedrich, and Hartmut Bossel. Ein Bärendienst für die Kernenergie. Stellungnahme zur Kritik der KFA Jülich a. d. 'Energiewende'. Freiburg i. Br.: Inst. f. angewandte Ökologie, 1982.

Nonn, Christoph Die Ruhrbergbaukrise. Entindustrialisierung und Politik, 1958-1969.

Göttingen: Vandenhoeck \& Ruprecht, 2001.

Odum, Howard T. Environment, Power, and Society. New York: Wiley-Interscience, 1971. Parlamentarische Enquete-Kommission [PEK]. "Bericht der Enquete-Kommission 'Zukünftige Kernenergie-Politik'.” Drucksache 8/2628. Bonn: Deutscher Bundestag, 1980. Parlamentarische Enquete-Kommission [PEK]. "Schutz der Erde." Dritter Bericht der EnqueteKommission "Vorsorge zum Schutz der Erdatmosphäre” des 11. Deutschen Bundestages (Drucksache 11/8020). Bonn: Deutscher Bundestag, 1990. 
Porter, Theodore Trust in Numbers: The Pursuit of Objectivity in Science and Public Life. Princeton: Princeton University Press, 1995.

Price, Don The Scientific Estate. Cambridge, MA: Harvard University Press, 1965.

Radkau, Joachim Aufstieg und Krise der deutschen Atomwirtschaft 1945-1968. Verdrängte Alternativen in der Kerntechnik und der Ursprung der nuklearen Kontroverse. Reinbek bei Hamburg: Rowohlt, 1983.

Schmitz, Kurt and Voß, Alfred "Energiewende? Analysen, Fragen und Anmerkungen zu dem vom Öko-Institut vorgelegten "Alternativ-Bericht"." Aktuelle Beiträge zur Energiediskussion Nr. 2, Jül-Spez-73. Jülich: Kernforschungsanlage Jülich, 1980.

Seefried, Elke "Experten für die Planung? „Zukunftsforscher“ als Berater der Bundesregierung 1966-1972/73." Archiv für Sozialgeschichte 50 (2010): 109-152.

Seefried, Elke "Prognostik zwischen Boom und Krise. Die Prognos AG und ihre Zukunftsprognosen für die Entwicklung der Bundesrepublik in den sechziger und siebziger Jahren.” In Zukunftswissen. Prognosen in Wirtschaft, Politik und Gesellschaft seit 1900, edited by Heinrich Hartmann and Jakob Vogel, 76-106. Frankfurt and New York: Campus, 2010.

Thompson, Michael "Among the Energy Tribes: A Cultural Framework for the Analysis and Design of Energy Policy.” Policy Sciences 17, no. 3 (1984): 321-339.

Tilly, Charles “Contentious Repertoires in Great Britain, 1758-1834.” Social Science History 17, no. 2 (1993): 253-280.

Tse-Tung, Mao On Guerrilla Warfare. Champaign, IL: University of Illinois Press, 1961.

Van Lente, Harro and Arie Rip. "Expectations in Technological Developments: An Example of Prospective Structures to be Filled in by Agency." In Getting New Technologies 
Together: Studies in Making Sociotechnical Order, edited by Cornelis Disco and Barend van der Meulen, 202-230. Berlin: Walter de Gruyter, 1998.

Weingart, Peter, Anita Engels, and Petra Pansegrau. "Risks of Communication: Discources on Climate Change in Science, Politics and the Mass Media." Public Understanding of Science 9, no. 3 (2000): 261-283.

Wessels, Theodor, Die Energie-Enquete : Ergebnisse und wirtschaftspolitische Konsequenzen, Tagungsberichte des Energiewirtschaftlichen Instituts an der Universität Köln, Heft 12. München: Verlag R. Oldenbourg, 1962.

Wynne, Brian "The Institutional Context of Science, Models, and Policy: The IIASA Energy Study." Policy Sciences 17, no. 3 (1984): 277-320.

${ }^{1}$ On "policy instruments," see Pierre Lascoumes and Patrick Le Galès, "From the Nature of Instruments to the Sociology of Public Policy Instrumentation,” Governance 20, no. 1 (2007): 1-21.

$\mathbf{2}$ Technoscientific innovations have increasingly become embedded in future-oriented narratives expressed in forecasts, roadmaps, scenarios, and so on that aim to convince investors and the general public of the necessity and positive effects of the innovation. See PierreBenoît Joly, "On the Economics of Techno-Scientific Promises," in Madeleine Akrich, Yannick Barthe, Fabian Muniesa, Philippe Mustar, eds., Débordements. Mélanges Offerts à Michel Callon (Paris: Presse des Mines, 2010), 203-222. 
${ }^{3}$ The German notion "Energiewende," derived from "Wende," can best be translated as "U-turn" (in sailing or more generally conducting); it describes a more radical policy change than the English term "energy transition."

${ }^{4}$ On public controversies as moments "unsettling" routines, convictions and actor-coalitions, see Mike Hulme, "After Climategate ... Never the Same," in Exploring Climate Change through Science and in Society: An Anthology of Mike Hulme's Essays, Interviews and Speeches (Abingdon, UK: Routledge, 2013), 252-264.

${ }^{\mathbf{5}}$ A similar argument is made by Christian Dieckhoff, Modellierte Zukunft. Zur Theorie und Praxis von Energieszenarien im Kontext Wissenschaftlicher Politikberatung (PhD diss., Karlsruher Institut für Technologie, 2014).

${ }^{6}$ Founded by the US Air Force with the support of the Ford Foundation, RAND has been one of the pillars of post-war American scientific and intellectual hegemony. Herman Kahn developed the scenario methodology in his studies on nuclear war at RAND. On the role of the RAND Corporation in futurology, see Jenny Andersson, "The Great Future Debate and the Struggle for the World," American Historical Review 117, no. 5 (2012): 14111431.

${ }^{7}$ Gabriele Hecht, The Radiance of France: Nuclear Power and National Identity after World War II (Cambridge, MA: MIT Press, 1998)

${ }^{8}$ Jenny Andersson and Egle Rindzevičiūtè, "The Political Life of Prediction: The Future as a Space of Scientific World Governance in the Cold War Era," Les Cahiers européens de Sciences Po 4 (2012): 1-25. 
${ }^{9}$ Donella H Meadows, Dennis L Meadows, Jorgen Randers, William W Behrens III, The Limits to Growth: A Report to the Club of Rome (New York: Universe Books, 1972)

${ }^{10}$ Paul R Ehrlich, The Population Bomb (New York: Sierra Club/Ballantine Books, 1968); Garrett Hardin, “The Tragedy of the Commons," Science 162 (1968): 1243-1248.

${ }^{11}$ Ossip K Flechtheim, Futurologie-Der Kampf Um die Zukunft (Köln: Wissenschaft und Politik, 1970).

12 Jenny Andersson, this volume.

${ }^{13}$ International Institute for Applied Systems Analysis [IIASA], Energy in a Finite World: Paths to a Sustainable Future (Cambridge, MA: Ballinger Publishing Company, 1981).

${ }^{14}$ See Eglè Rindzevičiūtè, this volume.

${ }^{15}$ Don Price, The Scientific Estate (Cambridge, MA: Harvard University Press, 1965).

${ }^{16}$ Early on, the trend to a multiplication of expert committees was criticized as a "scientizaton of politics" undermining democracy. See Jürgen Habermas, "Verwissenschaftlichte Politik in Demokratischer Gesellschaft,” in H. Krauch, W. Kunz, and H. Rittle, eds., Forschungsplanung (München: Wien, 1966), 130-144.

17 Theodore M Porter, Trust in Numbers: The Pursuit of Objectivity in Science and Public Life (Princeton: Princeton University Press, 1995).

${ }^{18}$ Alain Desrosières, Pour une Sociologie Historique de la Quantification. L'argument Sociologique I (Paris: Presses de l'Ecole des Mines, 2008).

${ }^{19}$ Porter, Trust in Numbers, 43. 
${ }^{20}$ Robert K. Merton, “The Self-Fulfilling Prophecy,” Antioch Review 8, no. 2 (1948): 198-210.

${ }^{21}$ Donald Mackenzie, "Making Things the Same: Gases, Emission Rights and the Politics of Carbon Markets," Accounting, Organizations and Society 34, no. 3-4 (2009): 440-455.

22 Thomas Baumgartner and Atle Midttun, The Politics of Energy Forecasting: A Comparative Study of Energy Forecasting in Western Europe and North America (Oxford: Clarendon Press, 1987).

${ }^{23}$ Jean-Charles Hourcade, "Les modèles dans les débats de politiques climatiques : entre le Capitole et la roche Tarpéienne?," in Amy Dahan, ed., Les modèles du futur (Paris: La Découverte, 2007), 140-164.

${ }^{24}$ Brian Wynne, "The Institutional Context of Science, Models, and Policy: The IIASA Energy Study," Policy Sciences 17, no. 3 (1984): 277-320.

${ }^{25}$ Michael Thompson, “Among the Energy Tribes: A Cultural Framework for the Analysis and Design of Energy Policy,” Policy Sciences 17, no. 3 (1984): 321-339.

${ }^{26}$ For this notion, see Sheila Jasanoff, "The Idiom of Co-Production,” in Sheila Jansoff, ed., States of Knowledge: The Co-Production of Science and Social Order (London, New York: Routledge, 2004), 1-12.

${ }^{27}$ German corporatism was characterized by a network of personal and institutional interconnections between major companies, banks and energy utilities. See Jürgen Beyer, “Deutschland Ag A.D.: Deutsche Bank, Allianz und das Verflechtungszentrum Großer Deutscher Unternehmen,” MPIfG Working Paper 02/4 (2002). 
${ }^{28}$ Kai Kleinwächter, “Das „Eiserne Pentagramm“-Strommarktregulierung in Deutschland,” in Lutz Kleinwächter, ed., Deutsche Energiepolitik (Potsdam: Brandenburgische Landeszentrale für politische Bildung, 2007), 65-79.

${ }^{29}$ Coal played an important role in German post-war history, as the recovery of the coal extraction industry was synonymous with national reconstruction as it gave both miners work and families coal for heating. This symbolic importance is backed by a strong actorcoalition composed of trade unions, energy utilities, state governments and the Social Democratic Party.

${ }^{30}$ Klaus Michael Meyer-Abich and R. A. Dickler, "Energy Issues and Policies in the Federal Republic of Germany," Annual Review of Energy 7 (1982): 221-259.

${ }^{31}$ Christoph Nonn, Die Ruhrbergbaukrise. Entindustrialisierung und Politik, 1958-1969 (Göttingen: Vandenhoeck \& Ruprecht, 2001), 173-175.

32 The biggest unit for electricity production in 1964 had an output of 300MW. Ten years later, in 1974, this number had risen to 700MW (coal) and 1300MW (nuclear).

${ }^{33}$ For an overview over forecasts in this period, see Michael Kraus, Energieprognosen in der Retrospektive. Analyse von Fehlerursachen der Prognose/Ist-Abweichungen von Energiebedarfsschätzungen in der Bundesrepublik Deutschland von 1950 Bis 1980, (PhD diss., Universität Karlsruhe, 1988), 18.

${ }^{34}$ Despite its denomination as "Energie-Enquete," this commission did not have the same features as the two Enquete Commissions discussed later. In particular, it did not include 
the participation of experts as regular members of the commission (see next sections for more details).

${ }^{35}$ The Arbeitsgemeinschaft deutscher wissenschaftlicher Institute was led by

Energiewirtschaftliches Institut (EWI). See next section for more details on EWI.

${ }^{36}$ On the methodology, see Theodor Wessels, Die Energie-Enquete : Ergebnisse und wirtschaftspolitische Konsequenzen, Tagungsberichte des Energiewirtschaftlichen Instituts an der Universität Köln, Heft 12 (München: Verlag R. Oldenbourg, 1962).

37 These included direct regulations like the Verstromungsgesetz and the Kohlezollkontingentgesetz, as well as a corporatist agreement between electricity companies and industry to use a minimum amount of domestic coal (Jahrhundertvertrag, 1977), a measure financed through the introduction of a levy on electricity prices. See Annika Krisp, Der Deutsche Strommarkt in Europa-Zwischen Wettbewerb und Klimaschutz (PhD diss., Fachbereich Sozial- und Kulturwissenschaften der Justus-LiebigUniversität Gießen, 2007), 26, 27.

${ }^{38}$ Joachim Radkau, Aufstieg und Krise der Deutschen Atomwirtschaft 1945-1968. Verdrängte Alternativen in der Kerntechnik und der Ursprung der Nuklearen Kontroverse (Reinbek bei Hamburg: Rowohlt, 1983), 113.

${ }^{39}$ This is particularly true for forecasts after 1965. Based on extrapolations of evolutions in the 1950s and 1960s, they prognosticated a doubling of energy demand per decade. See Hans Diefenbacher and Jeffrey P. Johnson, "Energy Forecasting in West Germany: Confrontation and Convergence," in Thomas Baumgartner and Atle Midttun, eds., The 
Politics of Energy Forecasting. A Comparative Study of Energy Forecasting in Western Europe and North America (Oxford: Clarendon Press, 1987), 61-84.

${ }^{40}$ Meyer-Abich and Dickler, "Energy Issues," 223.

41 Joly, "On the Economics."

${ }^{42}$ Uwe Fraunholz, Thomas Hänseroth, and Anke Woschech, "Hochmoderne Visionen und Utopien. Zur Transzendenz Technisierter Fortschrittserwartungen," in Uwe Fraunholz and Anke Woschech, eds., Technology Fiction. Technische Visionen und Utopien in der Hochmoderne (Bielefeld: transcript, 2012), 24

${ }^{43}$ Kraus, Energieprognosen, 60.

${ }^{44}$ Elke Seefried, “Experten Für die Planung? „Zukunftsforscher“ Als Berater der Bundesregierung 1966-1972/73,” Archiv für Sozialgeschichte 50 (2010): 109-152.

${ }^{45}$ Other economic research institutes important in the energy field include Deutsches Institut für Wirtschaftsforschung (DIW, Berlin, 1925), financed by the federal state and the Land Berlin, and Prognos AG, a Suisse institute founded in 1959. WirtschaftsWissenschaftliches Institut (WWI, 1946), the major economic institute of the trade unions, did not have a separate energy division. Technical universities and research institutes with atomic energy departments also played an important role (e.g., Technische Hochschule Karlsruhe, Kernforschungszentrum Jülich).

${ }^{46}$ IIASA's 1981 energy forecast innovated by developing a system's approach. See Bill Keepin, “A Technical Appraisal of the IIASA Energy Scenarios," Policy Sciences 17, no. 3 (1984): 199-276. 
${ }^{47}$ For further discussion of the links of economic research institutes to actors in the energy field see Kraus, Energieprognosen, 25.

${ }^{48}$ On the crisis of forecasting in the 1970s, see Elke Seefried, "Prognostik Zwischen Boom und Krise. Die Prognos AG und Ihre Zukunftsprognosen Für die Entwicklung der Bundesrepublik in den Sechziger und Siebziger Jahren," in Heinrich Hartmann and Jakob Vogel, eds., Zukunftswissen. Prognosen in Wirtschaft, Politik und Gesellschaft Seit 1900 (Frankfurt, New York: Campus, 2010), 76-106.

${ }^{49}$ Berndt Lehbert, "Untersuchung der Kurz- und Langfristigen Elastizitäten der Energienachfrage in Bezug auf die Energiepreise in der Bundesrepublik Deutschland,” in Kieler Arbeitspapiere Vol. 59 (Kiel: Institut f. Weltwirtschaft, 1977).

${ }^{50}$ Published forecasts for West Germany went from zero to seven per year in the 1950s and 1960s to seven to thirty per year in the 1970s. See Kraus, Energieprognosen, 18.

51 The Reagan administration (1981-1989) phased out the incentive programs in the mid-1980s.

52 Over 16,000 wind turbines of a total of $1.7 \mathrm{GW}$ were installed in California between 1981 and 1990; see John K. Kaldellis and Dimitris Zafirakis, “The Wind Energy (R) Evolution: A Short Review of a Long History," Renewable Energy 36, no. 7 (2011): 1887-1901.

${ }^{53}$ In the late 1970s, private companies like ARCO Solar constructed in California the world's largest photovoltaic (PV) manufacturing facilities, and federal and regional administrations created Solar One, the first large-scale thermal solar tower power plant. These developments were widely discussed in Germany, in particular by politicians like 
Herman Scheer (SPD) and researchers like Carl Friedrich von Weizsäcker and his son Ernst Ulrich von Weizsäcker (both physicists).

${ }^{54}$ Howard T. Odum, Environment, Power, and Society (New York: Wiley-Interscience, 1971).

${ }^{55}$ E.g. Alan Kneese, Robert U. Ayres, and Ralph C. D’Arge, Economics and the Environment: A Materials Balance Approach (Baltimore: John Hopkins Press, 1970).

${ }^{56}$ Michael Common and Sigrid Stagl, Ecological Economics: An Introduction (Cambridge, UK: Cambridge University Press, 2005).

${ }^{57}$ Robert A. Frosch and Nicholas E. Gallopoulos, "Strategies for Manufacturing," Scientific American 261, no. 3 (1989): 144-152

${ }^{58}$ Amory B. Lovins, "Energy Strategy: The Road Not Taken,” Foreign Affairs 55 (Fall 1976): 65-96; Amory B. Lovins, Soft Energy Paths: Toward a Durable Peace (New York: Penguin Books), 1977.

59 Joel B. Hagen, An Entangled Bank: The Origins of Ecosystem Ecology (New Brunswick, NJ: Rutgers University Press, 1992).

${ }^{60}$ Klaus Michael Meyer-Abich, Energieeinsparung Als Neue Energiequelle. Wirtschaftspolitische Möglichkeiten und Alternative Technologien. Mit Einem Vorwort von Carl Friedrich von Weizsäcker (München: C. Hanser, 1979).

${ }^{61}$ Klaus Michael Meyer-Abich and Bertram Schefold, eds., Wie Möchten Wir in Zukunft Leben? Die Sozialverträglichkeit von Energiesystemen. Band 1 (München: C. H. Beck, 1981). 
${ }^{62}$ Florentin Krause, Hartmut Bossel, and Karl-Friedrich Müller-Reissmann, Energie-Wende: Wachstum und Wohlstand Ohne Erdöl und Uran. Ein Alternativ-Bericht des Öko-Instituts (Frankfurt am Main: Fischer, 1980).

${ }^{63}$ While bottom-up models do a better job in representing the effects of specific policies or technological developments on energy demand, they aren't designed to calculate the macroeconomic effects of these policies. "Coupled" models combine both modeling traditions.

${ }^{64}$ Paul Hockenos, "The Energiewende," Zeit Online (November 15, 2012). Amory B. Lovins is the first name the authors cite in their acknowledgment section. See Krause, Bossel, and Müller-Reissmann, Energie-Wende, 10.

${ }^{65}$ Although probably not directly attributable to him, the proverbial quote was referring to Mao Tse-Tung's writings on tactics of guerilla warfare. See Mao Tse-Tung, On Guerrilla Warfare (Champaign, IL: University of Illinois Press, 1961).

${ }^{66}$ Such transformations were predicted at that time by some sociologists.

${ }^{67}$ Krause, Bossel, and Müller-Reissmann, Energie-Wende, 10.

${ }^{68}$ Ibid., 27.

${ }^{69}$ Ibid., 31. This was later popularized by Amory B. Lovins through the notion of "Negawatt Power Plant". See Amory B. Lovins, "The Negawatt revolution." Across the Board XXVII, no. 9 (1990): 18-23.

${ }^{70}$ Ibid., 156-166. 
${ }^{71}$ In energy forecasts, business-as-usual or reference scenarios sketch futures where no policy intervention is assumed and major trends continue unchanged. They are often used as a backdrop against which different policy options are discussed. We use the terms "reference scenario" and "business as usual" as synonyms.

${ }^{72}$ Against the IIASA World scenario that the authors call "suicide scenario," see Krause, Bossel, and Müller-Reissmann, Energie-Wende, 167.

${ }^{73}$ Ibid., 155.

${ }^{74}$ Kenneth Ewart Boulding, "The Economics of the Coming Spaceship Earth,” in Henry E. Jarrett, ed., Environmental Quality in a Growing Economy (Baltimore: Resources for the Future/Johns Hopkins University Press, 1966), 3-14.

${ }^{75}$ Herman E. Daly, Toward a Steady-State Economy (San Francisco, CA: Freeman, 1973)

${ }^{76}$ Die Zeit and Der Spiegel published (very) brief discussions in which they gave more space to its detractors than to the actual study. See Günter Haaf, "In den Kloaken der Zivilisation.” Die Zeit 42 (10 October 1980): 101; Der Spiegel, „Tüftler im Grünen.“ Der Spiegel 36 (1980), 225-229.

${ }^{77}$ Kurt Schmitz and Alfred Voß, "Energiewende? Analysen, Fragen und Anmerkungen zu dem vom Öko-Institut vorgelegten "Alternativ-Bericht"." Aktuelle Beiträge zur Energiediskussion Nr. 2, Jül-Spez-73 (Jülich: Kernforschungsanlage Jülich, 1980).

${ }^{78}$ Der Spiegel "Jülicher Eigentor." Der Spiegel 48 (1980): 140. See also Karl-Friedrich MüllerReissmann and Hartmut Bossel, Ein Bärendienst Für die Kernenergie. Stellungnahme zur 
Kritik der Kfa Jülich A.D. 'Energiewende’ (Freiburg i. Br.: Inst. f. angewandte Ökologie, 1982).

${ }^{79}$ Krause, Bossel, and Müller-Reissmann, Energie-Wende, 10.

${ }^{80}$ Francis Chateauraynaud, "Des prises sur le futur. Regard analytique sur l'activité visionnaire." In Du risque à la menace. Penser la catastrophe, edited by D. Bourg, P.-B. Joly, and A. Kaufmann (Paris: PUF, 2014), 287-309.

${ }^{81}$ Hans Christoph Binswanger, Holger Bonus, and Manfred Timmermann, Wirtschaft und Umwelt. Möglichkeiten einer ökologieverträglichen Wirtschaftspolitik (Stuttgart: Kohlhammer, 1981).

${ }^{82}$ Huber, a sociologist and economist inspired by Nikolai Kondratjew’s and Joseph Schumpeter's work on long economic cycles, posited that a new economic cycle based on microelectronics and new media and information technology would replace resource intensive industrialization.

${ }^{83}$ Jänicke, a political scientist, concentrated on "state failure" in environmental and social policy and possible reforms that would enable society to redirect the economy in an environmentally friendly way.

${ }^{84}$ For a history of this concept, see Arthur P. J. Mol and Martin Jänicke, “The Origins and Theoretical Foundations of Ecological Modernisation Theory," in Arthur P. J. Mol, David A. Sonnerfeld, and Gert Spaargaren, eds., The Ecological Modernisation Reader: Environmental Reform in Theory and Practice (London and New York: Routledge, 2009), 17-27. 
${ }^{85}$ For an analysis and an overview, see Wilhelm Knelangen, "Enquete-Kommissionen," in Uwe Andersen and Wichard Woyke, eds., Handwörterbuch des Politischen Systems der Bundesrepublik Deutschland. (4te Auflage) (Opladen: Leske+Budrich, 2000), 157-159.

${ }^{86}$ Article 56 of the internal rules of procedure (Geschäftsordnung) of the Bundestag. URL: http://www.bundestag.de/bundestag/aufgaben/rechtsgrundlagen/go_btg/go07/245166 [retrieved 26.01.2015]

${ }^{87}$ Knelangen, "Enquete-Kommissionen."

${ }^{88}$ Sheila Jasanoff, Designs on Nature: Science and Democracy in Europe and the United States (Princeton: Princeton University Press, 2005).

${ }^{89}$ Jasanoff compares this to the American tradition of publicly orchestrated contradictory expertise, or to the British tradition of civil servant experts.

${ }^{90}$ Silke Beck, "Localizing Global Change in Germany," in Sheila Jasanoff and Marybeth LongMartello, eds., Earthly Politics: Local and Global in Environmental Governance (Cambridge, MA and London: MIT Press, 2004), 173-194.

${ }^{91}$ For an analysis of the working of the commission and its political impact, see Cornelia Altenburg, Kernenergie und Politikberatung. Die Vermessung einer Kontroverse (Wiesbaden: VS Verlag für Sozialwissenschaften, 2010); Cornelia Altenburg. "Wandel und Persistenz in der Energiepolitik: Die 1970er Jahre und die Enquete-Kommission 'Zukünftige Kernenergie-Politik'," in Hendrik Ehrhardt and Thomas Kroll, Energie in der modernen Gesellschaft. Zeithistorische Perspektiven, (Göttingen: Vandenhoeck \& Ruprecht, 2012) 245-264. 
${ }^{92}$ PEK, “Bericht der Enquete-Kommission 'Zukünftige Kernenergie-Politik'.” in Drucksache 8/2628 (Bonn: Deutscher Bundestag, 1980).

${ }^{93}$ After a strong pro-nuclear position in the Godesberg program (1959), the SPD had become more and more divided internally on the nuclear question. The Party Congress in Nürnberg on the 27th of August 1986 decided that the new party line would be to abandon nuclear energy within ten years, a position confirmed in the Berlin program (1989).

${ }^{94}$ Der Spiegel, “Ozon-Loch, Pol-Schmelze, Treibhaus-Effekt, Forscher Warnen: Die KlimaKatastrophe,” Der Spiegel 33 (1986): 1.

${ }^{95}$ Peter Weingart, Anita Engels, and Petra Pansegrau, "Risks of Communication: Discources on Climate Change in Science, Politics and the Mass Media," Public Understanding of Science 9, no. 3 (2000): 261-283.

${ }^{96}$ A fourth, more radical Öko-Institut scenario was not included in the official energy paths of the commission.

${ }^{97}$ PEK, “Schutz der Erde,” Dritter Bericht der Enquete-Kommission “Vorsorge zum Schutz der Erdatmosphäre” des 11. Deutschen Bundestages (Drucksache 11/8020) (Bonn: Deutscher Bundestag, 1990), 453. Translated by the author.

${ }^{98}$ Francis Chateauraynaud, "Sociologie argumentative et dynamique des controverses: l'exemple de l'argument climatique dans la relance de l'énergie nucléaire en Europe," A contrario 16, no. 2011/2 (2011): 131-150. 
${ }^{99}$ Armin Grunwald, "Der Lebensweg von Energieszenarien-Umrisse eines Forschungsprogramms," in Christian Dieckhoff, Wolf Fichtner, Armin Grunwald, Sarah Meyer, Michael Nast, Linda Nierling, Ortwin Renn, Alfred Voß, Martin Wietschel, eds., Energieszenarien. Konstruktion, Bewertung und Wirkung_- Anbieter" und “Nachfrager” im Dialog (Karlsruhe: KIT Scientific Publishing, 2011).

${ }^{100}$ Nick Brown, Brian Rappert, and Andrew Webster, eds., Contested Futures. A Sociology of Prospective Techno-Science (Aldershot: Ashgate, 2000).

${ }^{101}$ Charles Tilly, “Contentious Repertoires in Great Britain, 1758-1834,” Social Science History 17, no. 2 (1993): 253-280.

${ }^{102}$ Harro Van Lente and Arie Rip, "Expectations in Technological Developments: An Example of Prospective Structures to Be Filled in by Agency," in Cornelis Disco and Barend van der Meulen, eds., Getting New Technologies Together: Studies in Making Sociotechnical Order (Berlin: Walter de Gruyter, 1998). 